\title{
Patients' experiences of peritoneal dialysis at home: a phenomenological approach
}

\author{
Maria Lúcia Araújo Sadala ${ }^{1}$ \\ Gabriela Azevedo de Souza Bruzos² \\ Estela Regina Pereira ${ }^{2}$ \\ Edwa Maria Bucuvic ${ }^{2}$
}

The aim of this study was to highlight the meaning of home dialysis as experienced by patients with chronic renal failure. The research design was influenced by Ricoeur's phenomenology. Nineteen patients from a Brazilian public hospital were interviewed, from May to September 2009. Interviews were guided by the question: "Tell me about your experiences lived undergoing PD". Findings unveiled the patients' perception of the drastic changes in their existence, consequent to disease and treatment; and the perception of themselves in that process. The feeling of anguish, physical pain and deprivations were part of living that condition. They foresee an uncertain future, depending on the expertise of health care providers and the demands on support of significant others. Findings suggest that individual aspects of patients' experiences must be considered if health care providers are to facilitate positive health outcomes.

Descriptors: Self-Care; Nursing; Peritoneal Dialysis; Qualitative Research.

\footnotetext{
${ }^{1}$ RN, Free Lecturer, Associate Professor, Departamento de Enfermagem, Faculdade de Medicina de Botucatu, Universidade Estadual Paulista "Júlio de Mesquita Filho", SP, Brazil. E-mail: sadal@uol.com.br.

2 RN, Unidade de Diálise, Hospital das Clínicas de Botucatu, Faculdade de Medicina de Botucatu, Universidade Estadual Paulista "Júlio de Mesquita Filho", SP, Brazil. E-mail: Gabriela - gabrielabruzos@gmail.com, Estela - bestela@uol.com.br, Edwa - edwa_ki@yahoo.com.br.
}

Corresponding Author:

Maria Lúcia Araújo Sadala

Universidade Estadual Pauslita "Júlio de Mesquita Filho"

Faculdade de Medicina de Botucatu

Hospital das Clínicas de Botucatu. Unidade de Diálise

Distrito de Rubião Júnior, $\mathrm{s} / \mathrm{n}$

CEP: 18618-970, Botucatu, SP, Brasil

E-mail: sadal@uol.com.br 


\section{A experiência vivida pelos pacientes em diálise peritoneal domiciliar: uma abordagem fenomenológica}

O objetivo deste estudo foi compreender a experiência da diálise peritoneal domiciliar, a partir da narrativa dos pacientes. A abordagem do estudo inspirou-se na fenomenologia hermenêutica de Paul Ricoeur. Foram entrevistados 19 pacientes na unidade de hemodiálise de um hospital público brasileiro, de março a setembro de 2009. As entrevistas foram orientadas pela questão: descreva sua experiência na diálise peritoneal. Os resultados desvelaram a percepção dos participantes sobre o significado da doença em suas vidas e as drásticas transformações pessoais sofridas nesse processo. Sentimentos de angústia e dor física foram acompanhados por importantes limitações pessoais e sociais, impostas pelo tratamento. Eles esperam por um futuro incerto, reconhecendo sua dependência da ajuda dos familiares e dos profissionais da saúde. Os resultados desvelam as dificuldades e a falta de perspectivas vividas pelos pacientes em diálise, demonstrando o papel crucial que cabe aos profissionais que os acompanham. Ajudá-los a desenvolver o autocuidado e maximizar sua qualidade de vida é prioridade na assistência a esses pacientes.

Descritores: Autocuidado; Enfermagem; Diálise Peritoneal; Pesquisa Qualitativa.

\section{La experiencia vivida por pacientes en diálisis peritoneal domiciliaria: un abordaje fenomenológico}

El objetivo de este estudio fue comprender la experiencia de la diálisis peritoneal domiciliaria, a partir de la narración de los pacientes. El abordaje del estudio se inspiró en la fenomenología hermenéutica de Paul Ricoeur. Fueron entrevistados 19 pacientes en la unidad de hemodiálisis de un hospital público brasileño, de marzo a septiembre de 2009. Las entrevistas fueron orientadas por la pregunta: describa su experiencia en la diálisis peritoneal. Los resultados revelaron la percepción de los participantes sobre el significado de la enfermedad en sus vidas y las drásticas transformaciones personales sufridas en ese proceso. Sentimientos de angustia y dolor física fueron acompañados por importantes limitaciones personales y sociales, impuestas por el tratamiento. Ellos esperan un futuro desconocido, reconociendo su dependencia de la ayuda de los familiares y de los profesionales de la salud. Los resultados revelan las dificultades y la falta de perspectivas experimentadas por los pacientes en diálisis, demostrando el papel crucial que le cabe a los profesionales que los acompañan. Ayudarlos a desarrollar el autocuidado y maximizar su calidad de vida es una prioridad en la asistencia a esos pacientes.

Descriptores: Autocuidado; Enfermería; Diálisis Peritoneal; Investigación Cualitativa.

\section{Introduction}

Chronic kidney disease (CKD) is a public health problem worldwide, often resulting in end-stage renal disease (ESRD) and necessitating renal replacement therapy (RRT). In Brazil, incidence and prevalence of ESRD are increasing; prognosis is still poor and costs of treatment are very high(1). Despite the country's striking socioeconomic disparities, access to medical services is universal, and even sophisticated medicine has been made accessible to all the people. Today, RRT centers exist virtually across the Brazilian territory, comprising 524 dialysis and 111 renal transplant units. Despite some occasional fatal accidents, dialysis has been a safe procedure in Brazil, with an annual mortality similar to that verified in developed countries ${ }^{(2)}$. Although peritoneal dialysis (PD) is indicated as a modality of RRT that benefits patients' quality-of-life, representing lower 
costs to the health care system, this modality of dialysis is used for approximately $10 \%$ of the dialysis population in our country ${ }^{(2)}$. To revert such trends, Brazilian academic centers and health institutions involved with RRT need to invest in research and educational programs related to peritoneal dialysis ${ }^{(1-2)}$.

After PD has been chosen by a medical team, physicians should decide between: i) manual exchanges of dialyzed fluid (CAPD), 4 to 5 times a day; ii) or the use of a cycler, which fills or drains the peritoneum with dialyzed fluid, during the night (APD).

PD is mainly a self-care modality, allowing patients to self-manage their own treatment and care. The specific self-management activities done by patients include performing dialysis procedures; caring for catheter and exit site*; taking medications; following diet and fluid limits; and conducting self-assessment, including observation for complications ${ }^{(3)}$. In this process, nurses have an educational role: they prepare the patients and relatives to carry out procedures of dialysis at home, encouraging patients to take over their own care supported by their family(4-8).

Studies of PD patients have shown that dialysis treatment dramatically changes patients' life. Besides the disease's physical symptoms, many become emotionally and/or socially disturbed because of social isolation and unpredictable course of illness ${ }^{(5,9-10)}$. Recent studies have focused on the experience of PD patients, stressing the importance of knowing their comprehension about disease and treatment. Those studies highlight differences between patients and healthcare providers' conceptions of health; and the imposition of the clinical imperative over the patients' personal imperative ${ }^{(3,7,11)}$. According to that conception, an author proposed(7) a nursing care model closer to patients' perspective of illness, adapting the care plan to each one's unique characteristics. This care model has similarities with the self-care model(12) and with Peplau's theory of therapeutic communication, focused on educating and developing patients as people experiencing their disease ${ }^{(13)}$. Those nursing theories focus on the educational aspects in the nurse-patient relationship by setting the nursing care's goal as stimulating people's capacity to control their own treatment.

To reach this goal, it is essential that nurses deeper understand the patients' perception of illness and treatment; and how they face the significant changes in their life as a result of kidney failure. In this sense, studies exploring patients' subjective experience, under their own point of view, can help healthcare providers come closer to the reality patients experience and allow them to understand the patients' needs better.

\section{Aim}

The aim of this study was to highlight the meaning of PD as experienced by patients with chronic renal failure.

\section{Design}

Narrative interviews were conducted with the study participants. A phenomenological-hermeneutic method was used to interpret the text, inspired by Paul Ricoeur's phenomenological hermeneutics(15). The method of interpreting the participants' interviews proceeds through three phases: naïve reading, structural analysis and comprehensive understanding, which constitute a dialectical movement between the whole and the parts of the text and between understanding and explanation(16). Each interview was regarded as a text. The focus of the analysis of the text was not what the texts said, but rather what participants said about the essential meaning of experiencing PD. First, a naïve reading was made of all the transcribed interviews as a whole, so as to gain a first vision of patients' experiences of undergoing PD. The naïve reading shows the direction the structural analysis may take. Second, a structural analysis was performed: it represented the methodological instance of interpreting the experience lived by participants. The participants' texts were divided into units of meaning (sentence, or parts of a sentence that answered the study question). The meaning units were reflected on against the background of the naïve understanding to validate the comprehension of the text; then, the convergences of all units of meaning were grouped into themes, formulating the results that expressed the experience lived. Third, a comprehensive understanding was developed, taking into account the authors' preunderstanding, the naïve reading and the structural analysis. The comprehensive understanding was read as a whole and interpreted in relation to relevant data from related literature(16).

\section{Participants and setting}

Study participants were: 8 males and 11 females; between 20 and 77 years (mean age 46 years); 14

* Care of the catheter and the exit site (where the catheter comes out of the body) is important to keep the catheter functioning and also to minimize the risk of developing an infection ${ }^{(14)}$. 
married, 2 single and 3 widowed; 7 independent in PD; 12 depending on relatives' help. As regards education, 2 participants were college graduates; 6 high-school graduates; 2 had not completed secondary education; 4 completed elementary school; 3 had not completed it; 2 were illiterate. Among participants: 3 worked, 4 had disability benefits, 4 were housewives and 8 were retired. Pre-requisite for participants' selection was being under PD for at least six months. Research was developed at the Hemodialysis Unit of a Brazilian University Hospital.

Data were collected during home visits. The patients were interviewed for between 30 and 60 minutes. Interviews were tape recorded and subsequently transcribed verbatim. A broad openended question was used to encourage narration: "Tell me about your experiences lived undergoing PD". Participants gave their informed consent to participate in the study, which was approved by the Ethics Committee at the Institution where it was developed (Opinion No. 523/08-CEP).

\section{Findings}

\section{Naïve understanding}

Living the experience of PD means experiencing feelings of uncertainty, anguish and difficulties since the moment of the communication of CKD diagnosis and the need for dialysis to replace renal function. Drastic changes cause a revolution in participants' lifestyles, resulting in damage to their life project. After adapting to the new reality, many are thankful and hopeful, despite suffering and difficulties lived in the treatment. They are aware of the fact that dialysis enables them to survive, but is not a cure for the disease. They know they will forever depend on their own self-care, as well as on care from their relatives, health care professionals and health care institution.

\section{Structural Analysis}

Three main themes emerged from structural analysis: Facing the world of renal failure and dialysis treatment; Living changes in one's own body, Sources of support. By seeking a better understanding of participants' texts, parts of statements (identified by the numbers of their statements) are focused on in the analysis, illustrating and clarifying the interpretation of findings.
Facing the world of renal failure and dialysis treatment

When questioned about their experience of PD, the participants recalled the first contact with the world of CKD and with renal replacement therapy. They described their anguish in the face of death; and the perception that they were launched into an unknown and frightening world, without escape. The treatment proposed by the healthcare team was the only way to survive. But, in practice, it appeared painful and aggressive, drastically limiting their activities and social life. In addition, it would last for a long and unpredictable time, until an unlikely kidney appeared to have a transplant. All participants reported their difficulties to accept and to adapt to those impositions. A young female patient described: The doctor said that I wasn't taking the treatment seriously. He called my attention and I cried inside her office. But it was very important for me. I said: Ooops! Let's improve, I'm doing everything wrong (P 5).

Realizing the efficacy of therapy, patients reported that they have adhered to treatment schedules: they decided to follow the severe dietary, fluid restrictions and limitations imposed by PD. After three years of dialysis, a participant exemplifies how she assimilated its need: I found out that with the treatment I feel good. And I do it by myself. I don't like to think whether I like it or not, or what might go wrong. I just do it. I don't like to put bad ideas in my head (P 11).

She found herself taken by the situation: she just allows herself to live in the temporality of the disease and the PD. Living time like that is understood as: the disease unravels in a continuum: I just do it as if $I$ were doing another kind of treatment. I face it naturally. It's something I need, so, I do it, no complaints, no nothing. It's good for me, right? (P 15).

Time lived is understood as a sequence of radical changes in the course of participants' life; actually, impositions that have shortened their time alive. They are connected to the machine many hours a day, every day. Associated to this, there is the threat of ceasing to exist. All the time has been marked by tension and anguish. A participant mentioned: Once I had an infection, I had to take antibiotics for 10 days and didn't get better. Then I had 5 shots in my veins and I still didn't get better. Then they did it again. After that, the machine would whistle again. That little rubber rolled inside. Then they gave me another medicine. But I still didn't get any better. Then they had put the central line again. So three times (P 18). 
Participants have realised that the illness became the focus of their lives and PF governs their existence. They became aware that that they could not do most of the things that they valued and enjoyed in the past. Forced changes encompassed the whole organization of their world, involving their home, job, social gatherings. Additionally, they financially affected the family: they had to leave or change their job. Patients and their family had to reorganize the house and adapt it to the PD. Several stretches of participants' discourse illustrated those changes, like the example below when the patient realized that the spaces previously inhabited, bedroom and bathroom, no longer correspond to what setting up the PD machine requires: In the first night we went home I had to go to the toilet and I couldn't. The bathroom was too far from my bedroom. My wife had to carry the machine so I could use the toilet. And there was no other way, see? The bathroom had to be closer (P 4).

Control and organization of the spaces used were lost. Another participant describes his home space as a prison: Dialysis has to be done at certain hours. But when it is time, you have to be home to do it, you can't go out. If you want to go out a little, it is very hard. Trouble is, you get stuck in the house like a prison (P 6).

The idea of inhabiting a prison was expressed by other participants, who had been feeling tied to the machine or slaves of the machine. Their bedroom, their bed, their night space, currently stands for a prison: I won't tell you that it is nice to lay there tied up the whole night. To have to pee there, in your bedroom (P 13).

House, bedroom, privacy, familiar places where people usually feel comfortable and protected became spaces of medicines, of a clean room, of lists of norms to prevent possible infections. On the other hand, the hospital environment that used to be scaring and cold becomes the place where meeting other people is nice, where patients receive care and support. A participant describes it as follows: And the healthcare providers who assist me, I feel they are my friends. I feel at home there (P 4).

The young revealed hope in soon having a kidney transplantation: dreaming of a future free from catheters, from bags and from the dialysis machine: Well, what was more important to me was when I joined the transplant waiting list to have an organ from a corpse. And I'm waiting (P 3). The older had not mentioned that possibility, probably because of knowing the long time to wait for an organ donor.

Living changes in one's own body

The experience lived of kidney failure and peritoneal dialysis has deeply affected the patients' way of relating with their body and its functions. They got emotional remembering when they were told their kidneys had failed. Many participants described how they felt marked by the loss of a part of their being. An old man saw himself dead when he entered the emergency service: I was scared. I thought that my life was over. I though. I said: now it's over. I felt really awful (P 3).

The unpredictable course of illness fosters uncertainty and fear. The disease and the treatment and, moreover, the failure of the vital organ and the decline of the physical abilities, have other effects: the participants reminded that they had lost their body as known before. Now they realized that they have appendices on it: the intrusive presence of objects and equipment like the dialysis machine; the tube inserted in the abdomen; the fluid stuffing the body for hours all day; the changes in weight and body shape; constant presence of pain and discomfort. A young woman recalled her earlier hospitalization: This thing of having a hole in your neck, of having them looking for a vein in you. Everything is very painful. It hurts to take a lot of shots. For me, the worst part is guessing how my stomach will be the next morning. The stomach is the worst part in a dialysis. You don't know whether your stomach will be all right next morning, whether you'll be able to eat. You feel sick and then you throw up. When I started I weighed 59 kilos and now I weigh 51 kilos (P 10).

Struggling against the deleterious effect of dialysis on their self, several respondents related their intention to assume responsible for their own care, even if they depend on other people in certain aspects. For those purposes, they do their best to follow procedures correct and carefully. They talked with deep concern about following health professionals' advice, using strictly aseptic techniques necessary to avoid a catheter infection: The only thing you have to be really careful in the treatment is infection. It's really hard if you get one. I've already had many. But by following the treatment correctly I feel fine (P 11).

Those efforts to resume the control of their body and their actions are connected to other participants' attitudes, aiming for the adaptation to the new reality and the return to a normal life. A young man described the practices that have become a normal routine in his daily life: I do everything by myself: I clean my bedroom, I take care of the PD. There are medicines, visits to the doctor. I have to take care both of the dialysis and of what I eat. (P 1). Another patient disclosed the intention of taking care of herself, of gaining independence: I see a lot of people doing dialysis and working. I said to the doctor: "God, why can't I leave my bed? (P 10). She has had kidney disease for 20 
years, 15 years after a kidney transplant, and has gone back to dialysis for 3 months. She is blind, has diabetes and hepatitis. In spite of being physically challenged, she has not lost hope of becoming independent.

An old man showed his resignation before an inevitable reality: I can't eat or drink anything forbidden, no way. But you get used to everything. At least I'm better than before ( $P$ 17). However, he remembered the suffering that has marked him when the healthcare team unsuccessfully tried to insert a catheter: The next time they inserted the catheter, it didn't work either. That hurts. They stuck a needle in my arm, I was bleeding, my arm got all swollen and they couldn't do it. But that is over and I'm alive. And it wasn't that bad, no (P 17).

\section{Sources of support}

In their narratives, participants relived the relationships with people around them: close relatives and healthcare providers, who care for them, at hospital and at home. They were aware that close relatives experienced numerous stressors related to illness and the maintenance of PD: their caregivers were affected by the same problems that affected them. Family support was described as essential to their adjustment of PD. Most of them have been extremely dependent on family assistance, as described by a young woman: I'm blind, I can't see anything. I depend on other people. My mother comes to visit me, calls me, see? She makes time to come, to call. And there is my husband. And for me it is better to do it at home ( $P$ 10).

A participant revealed gratitude for his wife's help, but resented becoming a burden: You depend on someone else for the dialysis. What I would like the most is if I could do the dialysis by myself, do you understand? (P 4). Another patient dolefully complained about the absence of his wife: I found dialysis very difficult in the beginning. My wife had passed away. So, it has been very hard (P 6).

Various family members have been involved in performing the dialysis procedures, as described by an old man: I have a daughter who is a nursing assistant, she helps a lot. And I have another daughter who takes care of the environment where I do the treatment. Everything is well taken care of. I just switch the machine on and off, got it? (P 3).

Physicians and nurses have accompanied them for years since the first symptoms. They take care of them; they are a part of their life. In addition to describing their dependence on their care, patients express feelings of gratitude and affection: Those people, healthcare providers, always treat us well. I've always been welcomed since I started my treatment here. It's been 8 years I have come here (P 5).
Even when healthcare providers called their attention about adhering to the treatment, the feeling of being welcomed and well cared prevailed: Sometimes they slap you on the wrist: Hey, you must improve here, improve there, right? But that's how they take care of us as if we were family. You feel at home here (P 5).

\section{Comprehensive understanding}

The chronically ill adults, as a result of their illness and continuous and demanded treatment, suffered from: leading restricted life; social isolation; being discredited and burdening others. In living that process, persons experience a fundamental form of suffering: the loss of self, as analyzed in various studies ${ }^{(5,17)}$. Those authors have analyzed that patients observe their self-image crumbing away, without the simultaneous development of equally value ones. Such conceptions of chronically ill patients' suffering were used in our study to understand and analyze the participants' narratives about experiencing PD. The aspects appointed as responsible for patients' loss of self can be observed in the three themes that emerged from the convergence of patients' narratives that are discussed next.

The PD conditions impose a number of losses on patients, which have radically transformed their lives, both qualitative and quantitatively: life has become poorer because many things are now impossible; and shorter, because there is little time left to effectively live. Added to that, their new habits involve the disease and its treatment; their social life becomes difficult; their job, for the majority, is non-existent; and they are tied to timetables and spaces dedicated to the PD, always depending on being accompanied by a family member. These characteristics described by the participants refer us to those conceptions of the loss of $\operatorname{self}^{(17)}$ : as a result of an incapacitating chronic disease, patients live a restricted life and experience social isolation, seeing themselves transformed into a burden for the family. Consequently, they feel diminished as to their value as a person, i.e. they feel discredited. There is not much place for advancements towards a normal life, which all of them seem to wish for. However, they have been fighting to be well, to get rid of their dependence from others, to recover the normality of life. The young ones have set as their goal a kidney transplant, the older ones to get well. Recent studies point at results similar to ours: peritoneal dialysis means a great impact on patients' lives, who suffer significant losses ${ }^{(5,18-19)}$. Uncertainty related to the future and physical and psychical suffering mark those patients, who find it very difficult to adapt to the new 
reality. They feel exhausted after many hours dedicated to the dialysis; the machine and pieces of equipment occupy their rest areas; their sleep is disturbed by the discomfort of the tubes, by the liquid coming into their body and the alarms ${ }^{(8,11)}$. However, patients adhere to the treatment, fighting for their lives and for leading life as normally as possible. Resuming control of their life plays an important role in facing the difficulties and restrictions of this chronic disease ${ }^{(7-8,11)}$. Even an illusion of control and future perspectives can be the basis for hope and optimism(3). A positive way of facing reality and difficulties can help patients preserve fundamental elements of a normal life, helping them keep command of their own decisions and actions ${ }^{(3)}$.

Describing their self-perception - consciousness of the body - participants told us about how the loss of the kidneys and the PD treatment exposed them to changes in their appearance and modes of perceiving and relating with their body. The essential losses they suffered along the illness diminished their former self-image and their self. Recent data from literature corroborate our findings: dialysis leads to great changes for personal identity and body image ${ }^{(8,11)}$. The bodily changes experienced in PD made them feel that the individual is not her/himself anymore, but rather another person, a disgusting person ${ }^{(19)}$. Implicit in those deleterious effects of illness on their self-image, we should analyze that the most significant source of loss of self is the inability to control one's self and life in ways that have been hoped for ${ }^{(17)}$. Besides changes in body images, our respondents described feelings of anguish and frustration when facing the loss of freedom: it means loss of body and life control. They have one thought: recover their normal life and be a normal person, again. They wish to be independent and normal(4-5). Some studies described the patients' need to look and feel more healthy and more like other people despite the disease and long term treatment $(7-8,11,20)$. At this point, patients are supposed to discover the extent of the limitations imposed by the illness, reevaluating life projects and setting new goals. Some authors considered that patients could overcome those difficulties by means of educational and professional support, aiming for the maintenance of their autonomy ${ }^{(7-8,19-20)}$.

Talking about people who share their experience, participants revealed their perception that family, health care professionals and institution are essential in their surviving. Such involvement and dependence always existed; even when the patient showed relative autonomy and performed dialysis procedure himself. As regards the relationship with health care professionals, participants perceived them as being constantly present; caring, informing and supervising care provision, professionals showed interest and availability, committing themselves to patients. Participants emphasize that the home visits are a differential characteristic in PD care, underlining the important participation of nurses, always close and attentive to their needs. Nurses were highlighted in their statements: they are seen as responsible for patients' education and learning of self-care in PD. The findings support previous research that suggests that patients on PD appreciate and recognize professional efforts to support them and tended to take more notice of the advice of registered nurses ${ }^{(11)}$. In spite of the frequent compliance with professional advices indicated in all studies, some authors analyzed that patients sometimes interpreted professional advices according to the way they live and to what they consider normal for them; sometimes showing a particular conceptualization of the treatment ${ }^{(7,11)}$.

Referring to family support, the study participants deplored the burden they represent to their relatives, provoking changes and losses in family life. Such findings support previous research that suggests that patients' families suffered significant impact when a relative undergoes dialysis treatment; they became emotional, social and financially disorganized and needed external support(17-18,21).

\section{Implications for nursing practice}

Findings of the study suggest that helping patients undergoing PD develop self-care and maximizing their quality of life should be a primary responsibility of healthcare providers in care delivery to those patients. Conceptions of self-care and patient-focused care seem to stand for the best path to reach this objective. As to this matter, nurses, due to their proximity with PD patients, play a decisive role in this educational process, aiming for the patients' adaptation and overcoming their difficulties. Asking patients about their level of understanding about disease and treatment, their sources of stress and uncertainties; the dialysis' impact on their lives: these are the ways to offer consistent and individualized assistance towards self-care; aiming to empower patients to recover self-esteem and value themselves as a person. Those interventions at the individual level will probably exert significant positive effects on patients and they may be incorporated into the care plan for terminal renal disease patients. 


\section{Final considerations}

The qualitative approach has added to and broadened the comprehension about how it is to live depending on PD: some aspects referring to patients' losses, physical problems affecting the self, their feeling of becoming a burden; and, especially for the older, the lack of perspectives about transplantation. The findings are likely to be an important source for nurses regarding a deeper understanding of the patients' needs and difficulties. It may be useful to direct the focus of nursing assessment on patients' specific needs.

Some aspects mentioned in study deserve further investigation, aiming at developing and enhancing the comprehension of care for patients undergoing PD, as follows: relatives' participation, nurses' and other professionals' perceptions of patient care and the effectiveness of educational work in PD.

\section{References}

1. Sesso R, Lopes AA, Thomé AS, Bevilacqua JL, Romão JE Jr, Lugon JR. Relatório do Censo Brasileiro de Diálise. J Bras Nefrol. 2008;30(4):233-8.

2. Zatz R, Romão JE Jr, Noronha IL. End-stage renal disease in selected groups. Kid Int. 2003;63:S131-4.

3. Curtin RB, Johnson HK, Schatell D. The peritoneal dialysis experience: insights from long-term patients. Nephrol Nurs J. 2004;31(6):615-24.

4. Lindqvis R, Sjödén PO. Coping strategies and quality of life among patients on continuous ambulatory peritoneal dialysis (CAPD). J Adv Nurs. 1998;27(2):312-9.

5. Jablonski A. The multidimensional characteristics of symptoms reported by end-stage renal disease patients on hemodialysis. Nephrol Nurs J. 2007;34:29-37.

6. Tsay SL. Self-efficacy training for patients with endstage renal disease. J Adv Nurs. 2003;43(2):370-5.

7. Polaschek N. Negotiated care: a model for nursing work in the renal setting. J Adv Nurs. 2003;42(4):355-63.

8. Lee A, Gudex C, Povlson N, Bonnevie B, Nielsen CP. Patients' views regarding choice of dialysis modality. Nephrol Dial Transplant. 2008;23(12):3953-9.

9. Machado LRC, Car MR. A dialética da vida cotidiana de doentes com insuficiência renal crônica: entre o inevitável e o casual. Rev Esc Enferm USP. 2003;37(3):27-35.

10. Chow SKY, Wong FKY. Health-related quality of life in patients. J Adv Nurs. 2010;66(8):1780-92.

11. McCarthy A, Winch S, Shaban R, Boys J. Compliance, Normality, and the Patient on Peritoneal Dialysis. Nephrol Nurs J. 2010;37(3):243-51.
12. Bub MBC, Medrano C, Silva CD. A noção de cuidado de si mesmo e o conceito de autocuidado na enfermagem. Texto Contexto Enferm. 2006;15(esp):152-7.

13. Peplau $\mathrm{H}$. Interpersonal relations in nursing. London: Macmillan Education; 1988.

14. Piraino B. Dialysis: The importance of peritoneal catheter exit-site care. Nat Rev Nephrol. 2010 May;6(5):259-60.

15. Ricoeur P. Tempo e narrativa. Campinas: Papirus; 1994.

16. Lindseth A, Norberg A. A phenomenological hermeneutic method for researching lived experience. Scand J Caring Sci. 2004;18(2):145-53.

17. Chamaz K. Loss of self: A fundamental form of suffering in the chronically ill. Sociol Health Illn. 1983;5(2): 168-97.

18. Bezerra KV, Santos JLF. O cotidiano de pessoas com insuficiência renal crônica em tratamento hemodialítico. Rev. Latino-Am. Enfermagem. 2008;16(4):686-91.

19. Lindqvist $R$, Carlsson $M$, Sjoden PO. Perceived consequences of being a renal failure patient. Nephrol Nurs J. 2000;27(3):291-7.

20. Gregory DM, Way CY, Hutchinson TA, Barrett BJ, Parfrey PS. Patients' perceptions of their experiences with ESRD and hemodialysis treatment. Qual Health Res. 1998;8(6):764-83.

21. Ashwanden $C$. The effects of acute renal failure on the family. EDTNA ERCA J. 2002; Suppl 2:56-8.
Received: Mar. $4^{\text {th }} 2011$ Accepted: Dec. $19^{\text {th }} 2011$ 